\title{
Assessing Government Transparency: An Interpretive Framework
}

Administration \& Society 20I8, Vol. 50(4) 50I-526

(C) The Author(s) 2015

DOI: I0.1I77/00953997/559834। journals.sagepub.com/home/aas

\section{Albert Meijer', Paul 't Hart', and Ben Worthy'}

\begin{abstract}
How can we evaluate government transparency arrangements? While the complexity and contextuality of the values at stake defy straightforward measurement, this article provides an interpretative framework to guide and structure assessments of government transparency. In this framework, we discern criteria clusters for political transparency-democracy, the constitutional state, and social learning capacity-and for administrative transparency-economy/efficiency, integrity, and resilience. The framework provides a structured "helicopter view" of the dimensions that are relevant for a contextual assessment of transparency. An illustrative case discussion of the introduction of Freedom of Information (FOI) in the United Kingdom demonstrates its utility.
\end{abstract}

\section{Keywords}

transparency, FOI, information

\section{Introduction}

Transparency is supposed to make governments less corrupt, more efficient, more democratic, and more legitimate (Hood \& Heald, 2006). Roberts (2006)

\footnotetext{
'Utrecht School of Governance, The Netherlands

${ }^{2}$ Birkbeck College, London, UK

\section{Corresponding Author:}

Albert Meijer, Utrecht School of Governance, Bijlhouwerstraat 6, 35 I I ZC Utrecht, The Netherlands.

Email: a.j.meijer@uu.nl
} 
describes how Freedom of Information (FOI) as an idea and a practice has spread around the world in the past decades and even authoritarian states like China are now embracing transparency. At the same time, there is much resistance to far-reaching forms of transparency, and not only from government bureaucrats clinging to convenient traditions. Etzioni (2010) argues that transparency is overrated and by no means able to produce the expected benefits and O'Neill (2002) argues that transparency erodes trust and undermines governance. Other skeptics highlight its opportunity costs and unintended consequences (Bannister \& Connolly, 2011; Erkkilä, 2012, pp. 21-28, 226-229).

These transparency debates imply a variety of assumptions, but the absence of a normative bedrock results in often confusing exchanges, "dialogues of the deaf" rather than a productive deliberative engagement. We fill this gap in the academic literature by developing a comprehensive framework for evaluating transparency. To escape the categorical and dichotomous nature of the discussions, we introduce a meta-level criteria map that can be used to interpret transparency debates and guide the (collective) assessment of specific transparency arrangements. Our framework forms the basis for an interpretative rather than a calculative evaluation of government transparency (Lagsten \& Goldkuhl, 2008; Werner, 1978): This interpretative assessment framework provides a structured "helicopter view" of the dimensions that are relevant for assessing both existing and proposed transparency arrangements. Our ambition is to develop a framework that can form the basis for an interpretative assessment of transparency in a specific context.

A key problem in transparency assessment is that the (political, administrative, institutional, cultural, demographic) contexts in which transparency is constructed vary considerably. Transparency is developed in democratic but also authoritarian states (Rodan, 2004), in adversarial but also consensual political cultures (Erkkilä, 2012), in countries with a highly developed or limited civil sector with strong NGOs and media (Welch, 2012) and for a highly educated and information-savvy or low-educated population (Bannister \& Connolly, 2011). We surmise, however, that the underlying value clusters at stake in designing and assessing government transparency are - or at least ought to be - broadly similar across contexts.

In the construction of the interpretative assessment framework, we start by making a distinction between transparency in the political and administrative realms of "government." Building an assessment framework of government at this level of abstraction is exceedingly complicated and needs to be based on a broad overview of normative approaches of government. After an exploration of previous efforts to categorize evaluative frameworks, we selected Bovens, Schillemans, and 't Hart's (2008) framework for accountability 
evaluation as well as Hood's (1991) typology of administrative values as building blocks for our frameworks. These meta-perspectives have proven to be useful for developing closely related assessment frameworks and they are both widely cited by other authors in the field.

We illustrate the applications of the framework we developed on the basis of Bovens et al. (2008) and Hood (1991) with reference to the case of FOI in the United Kingdom. We conclude that articulating these value sets and inducing stakeholders and evaluators to systematically engage in more structured discursive argumentation offers a conceptually rich yet methodically parsimonious way of assessing contextual transparency arrangements. This article contributes to the academic literature on government transparency that is already rich in comparative evaluation frameworks (see, for example, Ferreira da Cruz, Tavares, Marques, Jorge, \& De Sousa, 2015) by providing a structured framework with the dimensions that are relevant for a specific, contextual assessment of transparency.

\section{Two Realms: Political and Administrative Transparency}

The debate about government transparency takes place in two (interconnected) realms. The first is the political realm and it focuses on (participatory) democracy and the constitutional state (Fung, 2013; Naurin, 2006). Arguments in favor include the right to know, the contribution to a strong democracy, and checks and balances. Critics use the full catalogue of perversity, futility, and jeopardy arguments that change critics usually employ (Hirschman, 1991), but their core claim is that transparency breeds mistrust and undermines the legitimacy of public institutions. The overarching question in this realm is how and when transparency contributes to the democratic quality of government.

The second is the administrative realm and it focuses on managerial concerns related to the idea of "good governance" (Fung, Graham, \& Weil, 2007; Hood \& Heald, 2006; Meijer, 2007). While transparency is often introduced to curb corruption and stimulates more efficient decision making and public service delivery, it may in effect breed risk avoidance, myopia, middle of the road thinking, and the death of administrative entrepreneurship, and increases compliance and control costs (Heald, 2012; J. Roberts, 2009). The key question in this realm is how and when transparency contributes to the executive competence of government.

Both realms are highly connected since transparency arrangements that feed into democratic debates may also have consequences for debates about the government administration (Hood \& Heald, 2006; A. Roberts, 2006). 
And, vice versa, increasing administrative transparency can have political implications when seemingly technical administrative processes affect the impact or perception of political policy decisions or leaders. We acknowledge the permeability of the politics-administration dichotomy (Svara, 2001), but still develop separate sets of criteria for the two realms to enable evaluators. The interpretation of the assessments needs to take the various connections and interrelations between these realms into account.

\section{Assessing Transparency in the Political Realm: Toward a Framework}

In the political process, the key normative question is whether transparency strengthens or undermines our constitutional democracies. Three core value clusters are pertinent, according to Bovens et al. (2008): the democratic perspective, the constitutional perspective, and the social learning perspective. Each entails a distinctive criteria set for the evaluation of political transparency arrangements.

In the democratic perspective, a key issue is whether transparency arrangements strengthen the (information) position of citizens (Bovens et al., 2008). The position of citizens refers to their electoral role but also to their direct engagement in political agenda-setting, policy deliberation, and decision making. The basic argument in the democratic perspective is that citizens should be enabled to participate in the public sphere, as well as to oversee how their political representatives use their mandates. Transparency, in other words, is needed for public engagement, a precondition for a "strong democracy" (Barber, 1984). Information about the performance and integrity of politicians strengthens the information position of citizens and helps them to make better decisions in the electoral process (Piotrowski \& Borry, 2010).

The counterargument is that citizens do not have the capacity to properly process all the information about their governments that becomes available to them through the Internet (Margetts, 2011). A. S. Roberts (2012) convincingly argues that the idea that Wikileaks would strengthen the position of citizens has proved illusory: It has yielded mountains of data, but not necessarily coherent and easily processed "information." Nor is it clear that citizens are willing and able to make proper use of disclosed information. Recent studies point toward the public frequently using of "shortcuts" to understand complex topics and to interpretations being shaped by preexisting biases (James, 2011). Moreover, some theorists of democracy argue that a certain degree of "virtuous ignorance" may strengthen rather than undermine representative democracy (cf. Keane, 2009). 
In what Bovens et al. (2008, p. 231) call the constitutional perspective, the key issue is whether transparency strengthens or undermines institutional checks and balances. Good governance arises from a dynamic equilibrium between the various powers within the state; transparency is needed to curtail the abuse of executive power. Countervailing powers are the key to "keep the bastards honest." In that respect, proponents of government transparency cite U.S. Justice Brandeis' famous quote that "sunlight is the best disinfectant" (Freund, 1972): Bringing information out in the open will thwart incompetence and agency drift (Heald, 2012). Curtin and Meijers (1995) argue that transparency is an important addition to the systems of interinstitutional checks and balances that states have developed over time.

The idea of the open truth bringing us honest governments is appealing but A. S. Roberts (2012) argues that there is no such thing as the instantaneous and complete revelation of the truth: "Raw data must be distilled; the attention of the audience must be captured; and the audience must accept the message that is put before it" (p. 130). He concludes that processing transparency and making it result in better checks and balances requires hard work. A key issue in this perspective is the relation between transparency and accountability. While there may be a mutually supportive or complementary relationship, this cannot be taken for granted (Hood, 2010, 2006; Heald 2006). Transparency may even undermine accountability by reducing complex processes of accountability to "low-intelligence defensive box-ticking and oneway communication" (Hood, 2010, p. 992).

While trivializing existing checks and balances is one risk of transparency, the opposite risk is no less real: undue expansion of transparency to hold public office-holders in check. Heald (2003) stresses that increased monitorial capacity may eventually result in excessive politicization and dysfunctional surveillance. Small errors or flaws can be exaggerated by "moral entrepreneurs" to frame government as incompetent or unresponsive to the needs of citizens. A focus on minor mistakes on the basis of "neutral information" may result in misrepresentations of corrupt politicians and self-righteous elites. When these allegations are not embedded in proper procedures for debate, they may result in widespread mistrust and cynicism.

In the social learning perspective, the key issue is whether transparency strengthens the quality of public debate and collective problem-solving capacity. In this perspective, social learning processes are seen as the key to the "intelligence of democracy" (Lindblom, 1965). Specifically, debate is at the heart of modern democracies and therefore states should develop institutions that guarantee free and informed exchange of opinions (Dryzek \& Niemeyer, 2010; Habermas, 1981). Transparency is expected to add to the quality of this debate as it reduces the information asymmetry between the participants in 
public debates. It brings the Habermasian ideal of an open debate closer as all the relevant information becomes available to democratic actors and, as a consequence, relevant issues, assumption, and rationales can be openly debated.

The counterargument is that the provision of information is framed by dominant actors. De Fine Licht, Naurin, Esaiasson, and Gilljam (2013) argue that decision makers polish the reasons made public and conduct various forms of window-dressing and Grimmelikhuijsen (2012, p. 141) stresses that organizations "spin" a message to frame debates in a favorable manner. Meijer (2013) indicates that transparency is a strategic resource: Some actors want access to the resource, while others want to retain the resource for themselves. The outcome of these interactions should not be understood as "fishbowl transparency" but as a strategic representation of government decision making: Neutral information is an oxymoron.

In sum,

- In the democratic perspective, transparency may result in citizen empowerment and a stronger electoral and participatory position but also in differential access (digital divide; financial barriers) and utilization capacities (political competences of citizens).

- In the constitutional perspective, that thwart incompetence, prevent abuse of power and agency drift. It may also create pressure for watchdog expansion, moral entrepreneurship, and shock-horror self-dramatization.

- In the learning perspective, transparency may facilitate access to public debates and decision-making circuits, but there may also be sensemaking and meaning-making problems as all information is framed and spinned.

A general issue in all these perspectives is the opportunity costs of systems of transparency. In all three perspectives, the benefits may merit substantial investments in transparency, but there are also opportunity costs. Money spent on transparency cannot be used to strengthen other citizen participation, checks and balances or learning mechanisms in different-and possibly more effective - ways (Etzioni, 2010).

The key design question is how we can develop mechanisms and practices of transparency that bring advantages while not creating adverse or perverse effects (Dror, 1999). Finding the desirable position is not only about the extent of transparency but certainly also about the desirable mix of transparency mechanisms. In general terms, in the democratic perspective, transparency should strengthen civic competence across the political community and help to "roll back" existing differences in the information position between citizens and the state. In the constitutional perspective, transparency arrangements 
should strengthen institutional checks and balances without generating perverse effects such as risk avoidance, goal displacement, and dramatization. And in the learning perspective, the desirable position is one where public debates are fed by "rich feedback"-multisource, multiperspective, relevant, timely narratives - without overloading citizens.

Debating what constitutes a desirable level of transparency in a specific polity thus means analyzing the specific consequences from a democratic, a constitutional, and a learning perspective and debating what this means for the desirable mix of transparency mechanisms. The degree of consensus between stakeholders in a transparency design or assessment exercise can thus be ascertained systematically; the points of difference will be highlighted and can be subjected to rigorous debate. The multiperspectivist framework can be used to identify key assumptions, focus the evidence base, and cut down on sweeping assertions. We now use the case of FOI in the United Kingdom to highlight how the framework can be usefully applied.

\section{Assessing Transparency in the Political Realm: An Illustration}

The United Kingdom FOI Act has been subject to rigorous analysis through a series of academic studies (Hazell, Bourke, \& Worthy, 2012; Hazell, Worthy, \& Glover, 2010; Worthy, 2010, 2013) and inquiries by a Parliamentary Select Committee and the Ministry of Justice (MOJ 2012; Justice Committee, 2012). The academic studies sought to triangulate elite interviews with surveys of users, media analysis, and assessment of requests. The broad approach was to measure the legislation against stated objectives: whether FOI increased the "core" values of transparency and accountability and had the secondary effects of improved decision making and increased public trust, understanding, and participation (Hazell et al., 2010). Methodologically, the academic studies highlighted how FOI impacts depended on the perceptions and views of those involved, particularly senior officials, politicians, and the media (Worthy, 2010, 2013). The impact is contested between critics, particularly senior politicians, portraying FOI as "counterproductive" and supporters highlighting successful exposure. Even members of the same organization held very different views (Worthy, 2013). FOI sits within a broader suite of transparency instruments, from lobbying registers to Open Data (Heald, 2012; Moss \& Coleman 2014). Although it contains proactive components, FOI is primarily reactive, shaped by whether questions are asked or not and the bureaucratic response to themwith the differing response to legislators' expenses in the Westminster and Scottish Parliament, with "cover-up" versus total publication, a prime example (Dunion, 2011). 
Table I. FOI Requests in the United Kingdom (Hazell \& Worthy, 20I0; Worthy, Hazell, Amos, \& Bourke, 201 I).

\begin{tabular}{lcc}
\hline Requester & Local government (\%) & Central government (\%) \\
\hline Public & 37 & 39 \\
Journalist & 33 & 8 \\
Business & 22 & 8 \\
Academic & 2 & 13 \\
Campaigner & 0 & 12 \\
Other $^{\mathrm{a}}$ & 6 & 20 \\
\hline
\end{tabular}

a"Others" include use by political parties and use on behalf of another.

\section{Democratic Empowerment?}

The extent to which FOI serves to empower the public is dependent on who is using it (Meijer, Curtin, \& Hillebrandt, 2012). The overall shape of requests fits with the "iceberg effect" (Hazell et al., 2010, pp. 65-66; White, 2007) whereby a small percentage of cases attract a disproportionate amount of attention. There is no "mass involvement," as less than 1 in 1,000 citizens make an FOI request (Hazell \& Worthy, 2010). Instead, as Table 1, shows, FOI appears to be driven by a diverse mixture of the public, small groups of journalists, NGOs, and businesses (Worthy, 2010, 2013). The "public" is constituted of a small group of "politicized" requests with a wider, looser group using it for "micro-politics" or private interests (Worthy, 2013).

Requesters have been alternately characterized, somewhat pejoratively as the "usual suspects" or the active "minority" already involved in politics, or, more positively, as a politically motivated "vanguard" securing information and change for others (Dunion, 2011; Hazell et al., 2010).

Given the patterns of use above, there is little evidence of any "direct" empowerment of the public due to FOI (Hazell et al., 2010). Two detailed studies of the electoral consequences of the Members of Parliament expenses controversy found it had little impact on voting patterns and that the public were unwilling or unable to hold specific errant MPs to account (Pattie \& Johnston, 2012; Vivyan, Wagner, \& Tarlov, 2012). There is, however, evidence of indirect influence through proxies. To see FOI as a direct tool may be to misunderstand an instrument that works best in combination with what Keane calls other "monitory" bodies (Keane, 2009). Use by the media and MPs has highlighted important issues, from rendition to banking scandals. At local government level, NGOs have used FOI as an effective "information gathering" tool in a range of campaigns (Worthy, 2013). In this less direct 
sense, as the Justice Committee concluded, FOI has added to a greater culture of involvement (2012).

If the objective of the transparency arrangement is to empower citizens, additional mechanisms to strengthen civic competence in an equitable fashion, that is across the board of the relevant (groups within) the political community, would need to be considered. Both academic studies and postlegislative scrutiny have concluded that FOI has enhanced political accountability across all levels of government (Justice Committee, 2012; Worthy, 2010). It is now embedded within a range of other mechanisms (Worthy, 2013).

FOI has triggered a series of high profile scandals, most notably the exposure of MPs' use of their Parliamentary expenses in 2009. This led to ministerial resignations and a record number of MPs stepping down at the following general election (Hazell et al., 2012). The leader of the Scottish Conservatives and a Member of the Northern Irish Assembly stepped down following requests revealing impropriety and one Parish council resigned en masse following an FOI campaign (BBC, 2012; Hazell et al., 2010).

Underneath the controversy, there is also a daily flow of FOI driven accountability to central and local government on a range of more quotidian topics from planning to car parking (Justice Committee, 2012; Worthy, 2013). Dunion (2011) observes that "the real worth of freedom of information [is] to be found in the pages of the local rather than the national newspaper" (p. 458).

FOI has become part of the constellation of checks and balances within the U.K. system. Evidence from the United Kingdom points toward FOI working best alongside these other mechanisms and being most frequently used in combination with other mechanisms, such as the media, NGOs and, less frequently, MPs, as a "picture-building" tool to gather information for wider campaigns (Worthy, 2013). In the case of MPs' expenses, it worked alongside journalists, rulings from appeal bodies and the courts before been revealed via a leak (Hazell et al., 2012). It has become a new weapon in the armory of the formal and informal "watchdogs" of government.

Though FOI is widely accepted by officials, politicians are less tolerant. Partly because of the way in which they come into contact with FOI through the "high profile" checks, politicians frequently see it as an "abused" process (Worthy, 2013). In his memoirs, Tony Blair sighed: "For political leaders, it's like saying to someone who is hitting you over the head with a stick, 'Hey, try this instead,' and handing them a mallet ... it's used as a weapon" (Blair, 2010, pp. 516-517).

The Justice Committee (2012) acknowledges that "irregularities, errors, and inefficiency" prove "more newsworthy" and a type of use likely to attract politicians' attention (p. 17). Despite the diverse use outlined above, Blair's 
portrayal of FOI being wholly "abused" appears to be shared at senior levels by Ministers and officials (Justice Committee, 2012). In this sense, key actors' perceptions of how FOI is used are as important in defining the shape and impact as the actual statistics, which may in turn encourage resistance, game playing, or even attempts to change the Act (Worthy \& Hazell, 2013).

From the constitutional perspective, FOI clearly contributes to more checks and balances. The current debate focuses on the extent to which they also produce unintended consequences such as "politician slapping." This highlights the need to evaluate whether transparency can strengthen them without generating perverse effects such as risk avoidance, goal displacement, and dramatization.

\section{Social Learning?}

The Justice Committee (2012, p. 20) felt that the Act had not increased public understanding of politics or decision making generally. Indirectly however, the media use and coverage of FOI has undoubtedly played a role in informing the wider public on a range of matters from the War in Iraq to National Health Service (NHS) reform. More importantly, requesters, particularly at local government level, felt their understanding of specific issues had increased (Worthy, 2013).

The wider consequences of these learning processes are less clear. Information released may be limited by framing and bias (Hazell et al., 2012). Studies of U.K. local voting behavior point to a negativity bias in information received: Voters "punish" poor performing authorities but do not reward well performing ones (Boyle et al., 2009). The general "negativity bias" among the public is often amplified by media framing (James \& Moseley, 2014). Even the "learning effects" of the MPs' expenses effect was more nuanced than they appeared. To many voters, the scandal was a "confirmation" of their preexisting misgivings rather than a shock "revelation" that decreased their trust in politicians (Hazell et al., 2012). Despite media claims of an "expenses" election, the issue had little effect on voting patterns in the 2010 general election (Hazell et al., 2012; Pattie \& Johnston, 2012).

An assessment from the social learning perspective shows that FOI can potentially enrich social learning processes, but few FOI users felt it increased their general understanding. Framing and bias seem to hamper the contribution of transparency to social learning and negativity bias resulted in a selective usage of information for punishing poor performance and confirming misgivings about politicians. The question here is how transparency can feed public debates with open information about government while preventing public confusion and mistrust. 
In sum, applying our interpretative transparency assessment framework to the political realm helps to identify a variety of pros and cons of the current FOI arrangement. In addition, it raises three questions relevant to debates about current and future forms of FOI in the United Kingdom:

- Is there a need for additional measures to ensure that FOI as a mechanism of transparency does not only benefit a selective group of citizens but also results in broader forms of citizen empowerment?

- Is there a need for measures to limit the perverse effects of FOI as an element in a system of checks and balances such as risk avoidance, goal displacement, and dramatization?

- Is there a need for measures to ensure that FOI enriches public debates with open information about government performance and decision making while preventing public confusion and mistrust?

These questions can help to turn a polarized debate focusing on issues of trust in government into a broader and more pragmatic debate about adjustments and explorations that can help to construct broadly supported forms of transparency.

\section{Assessing Transparency in the Administrative Realm: Toward a Framework}

In the administrative realm, transparency is about providing information about the administrative processes inside executive government, the integrity of public officials, the implementation of public policy, and the provision of public services. The key normative question is whether transparency strengthens the quality of the executive branch of government (the public administration). Following Hood's (1991) well-known categorization of core administrative values, we discern three types of criteria commonly used to evaluate public administration: economy/efficiency, integrity, and resilience.

In the economy/efficiency perspective, the key evaluative question is whether transparency contributes to the achievement of policy objectives and whether it promotes the search for the most efficient ways of realizing these. The key imperative, Hood (1991) surmises, is to keep it lean and purposeful. Frugality is the gold standard of quality in this perspective. Conversely, waste, muddle, confusion, and inefficiency are the hallmarks of failure.

Institutional economists believe that better information will result in more rational behavior. For example, a dominant argument for school transparency is that it enables citizens to make better choices, which will create an incentive for better school quality (Meijer, 2007). Fung et al. (2007) argue that 
disclosure of inspection data enables citizens to evaluate private and public actors on the basis of neutral information and pressure from citizens is supposed to result in more effective regulation. There is certainly evidence to suggest this might be so. For example, Meijer et al. (2012, p. 21) highlight that transparency improves the quality of administrative decision making when factual misconceptions among implementers and service providers are challenged and corrected by citizens. Institutional memory is also seen as important to efficient government by preventing repetitive errors. Drew and Nyerges (2004) indicate that open and retraceable records are especially important when key actors come and go. Impersonal access to information about previous actions is then crucial to producing efficient government.

Various counterarguments have been presented. First, Heald (2012) highlights the administrative costs of complying with an ever-expanding wave of FOI requests or the maintenance and publication of data sets, without producing clear benefits for clients or delivery agencies. Institutionalizing transparency requirements forces service providers to spend substantial amounts of their resources on "producing" transparency, and responding to the feedback, demands, and critiques from citizens. Second, many if not most citizens will not be willing and able to effectively discern, combine, and use all the available data about administrative events, processes, and decisions effectively (Bannister \& Connolly, 2011). Meijer (2007) shows that school information tends to be processed and utilized systematically by a relatively limited group of citizens: Most citizens rely on shortcuts such as the opinion of their neighbors or articles in local newspapers rather than processing the complex school inspections reports. Third, transparency means that information about administrative processes within government also becomes available to third parties who might derive unfair advantages from it (Prat, 2005; Stiglitz, 1999, p. 18). Finally, transparency may enhance risk avoidance among bureaucrats (Bannister \& Connolly, 2011; Prat, 2005): In the eye of the public, administrative agencies may prefer tried and tested yet suboptimal, conservative approaches instead of bolder, more innovative yet potentially riskier approaches to enhancing effectiveness and efficiency.

In the integrity perspective, the key issue is whether transparency induces officials to use their mandates and the resources at their disposal to implement the public will and not for the advancement their own interests or those of particular others. The integrity maxim is to keep it honest and fair (Hood, 1991, p. 11). Rectitude - achievement of fairness, mutuality, the proper discharge of duties - is the standard of success, and malversation - unfairness, bias, abuse of office - the standard for failure.

There is some evidence that indicates that transparency indeed helps to curb corruption through exposure and "anticipated reactions." Piotrowski 
and Borry (2010) argue that transparency deters misappropriations as citizens can see how the money is spent. Park and Blenkinsopp (2011) find that transparency plays a key role in reducing corruption but, at the same time, they acknowledge that transparency as a method for deterring corruption has clear limits as government administrators have a certain right to privacy. A high level of transparency may expose, for example, the whereabouts and spending patterns of individual officials, blurring the boundaries between what the public gets to know about them "in role" and in "private." It is interesting to note that there are substantial differences between countries when it comes to public officials' privacy: While the U.S. government publishes the incomes of all civil servants, this would be unthinkable in many other countries. In addition, high levels of transparency could result in the "death of entrepreneurship" within the public sector: Civil servants and even private contractors performing public services may shun any form of risk.

From the resilience perspective, the key issue is whether transparency enhances the robustness and adaptive capacity of administrative systems in the face of ongoing and episodic, even spasmodic, changes, risks, and threats. Rodan (2004) highlights how Asian states enhanced their transparency after the economic crisis of the 1990s to restore faith in their economies. Fung (2013, pp. 195, 196) points at the fact that transparency can help to manage the risks that come from the harmful externalities that are produced as the consequence of ordinary activities of large organizations. The standard of success is resilience - achievement of reliability, adaptive capacity, and robustness (e.g., Comfort, Boin, \& Demchak, 2010)—while catastropherisk, breakdown, collapse - is the standard for failure.

Resilience has received relatively little attention in debates about government transparency, but it plays a key role in debates about reducing financial fragility (Draghi, Francesco, \& Merton, 2004). The public availability of information enables outsiders - such as international financial investors (Rodan, 2004) - to scrutinize government and to detect (financial) risks. The counterargument is that too much transparency may result in a self-fulfilling prophecy: financial risks may indeed result in catastrophes because they were exposed (J. Roberts, 2009). Similarly, publicly reporting school performance may result in exit behavior from "very weak" schools, setting in motion a vicious cycle of decline (cf. Meijer, 2007; van Twist, van der Steen, Kleiboer, Scherpenisse, \& Theissens, 2013). A similar pattern may occur in poor and/or unsafe neighborhoods: transparency about the state of the neighborhood may result in a vicious cycle of community decline through business, investor, and property buyers' reluctance to commit resources to the area. 
In sum,

- In the economy/efficiency perspective, transparency may result in policy error reduction and delivery optimization but also in an explosion of transaction costs (i.e., audit society burdens on executive branch).

- In the integrity perspective, transparency may result in the prevention and detection of transgressions but also in blame avoidance pathologies (end of "frank and fearless advice," oral culture, middle of the road thinking, death of entrepreneurship).

- In the resilience perspective, transparency may result in (financial) risk reduction, mitigation, and response capacity and also in selffulfilling prophecies and the amplification of "underperformance" through vicious cycles of exit behavior (e.g., around schools and in unsafe neighborhoods).

Similar to the political realms, there is a debate about the opportunity costs of transparency. The objectives of economy/efficiency, integrity, and resilience merit substantial investments, but the organization can no longer use these resources in other ways to strengthen the economy/efficiency, integrity, and resilience of public organizations.

As for the political realm, the multiperspectivist framework constructed above can be used as a map to interpret and assess debates about the desirable level of transparency in a specific administrative system. It suggests that one should design and assess administrative transparency from an economy/ efficiency, an integrity, and a resilience perspective, and debating what this means for the desirable variety and mix of transparency mechanisms.

\section{Assessing Transparency in the Administrative Realm: An Illustration}

We revisit the example of FOI in the United Kingdom. Again, the multiperspectivist framework is used to establish a set of specific questions that can help to structure the debate about current and future forms of transparency in the United Kingdom.

\section{Economy and Efficiency?}

It is not clear whether FOI increases efficiency, either through high profile exposures curbing "profligate" activity or through anticipated reactions, in part because FOI cannot be disentangled from other reforms with the same intent (Hazell et al., 2010). Central government departments and local authorities 
Table 2. Estimated Costs of FOI in the United Kingdom (Colquhoun, 2010;

Worthy, Hazell, Amos, \& Bourke, 20I I).

Body examining cost

Estimated cost $(\ell)$ per request

U.K. Central Government

293

Scottish Executive

189

Cornwall Council

150

Bexley Council

36

have identified improvements in internal processes such as records management (Hazell et al., 2010; Worthy, 2013). It may also have discouraged "extravagant" spending on, for example, foreign travel or credit cards (Justice Committee, 2012). However, as few FOI requests have focused on the policy process and on service delivery, and as the policy process is partly exempt from FOI, the actual impact on the efficiency of decision making is unclear (Worthy et al., 2011). The actual internal impact of FOI on processes appeared to vary from government department to department and between local authorities.

From the opposite perspective, the financial "costs" of FOI are frequently discussed. However, studies have come to varying figures as Table 2 shows.

The reason for the ambiguity is twofold. First, the costs of FOI are hard to determine and different methods reach very different conclusions (Colquhoun, 2010; Justice Committee, 2012). Measurement is further complicated by the fact that a small proportion of requests appear to consume a large amount of resources (Justice Committee, 2012, p. 29). Second, the cost is politically contentious as the "benefits . . cannot be usually costed" and feed the narrative of FOI as a burden (Justice Committee, 2012, p. 22). The supposed "costs" of FOI is one of the key arguments deployed by the opponents of FOI, alongside the Act's supposed damage to decision making (see below).

An assessment from the perspective of economy/efficiency highlights the unpredictability of the impact of FOI on government organizations. The key issues here seem to be the actual usage of information related to financial affairs by citizens and proactive transparency created by administrative leadership to stimulate economy and efficiency. The question is how to further develop the current FOI regime as to strengthen the overall focus on economy and efficiency through, for example, directed and proactive forms of transparency.

\section{Integrity?}

The integrity dimension may work either through anticipated reactions or exposure (Meijer et al., 2012). As outlined above, there have been a series of 
high profile exposures at central and local government level. There also has been some evidence of, for example, reduced spending by MPs or local councilors (Justice Committee, 2012). The expenses scandal triggered a wave of similar FOIs against local government, the police, and health service (Worthy, 2013). Indirectly, the Act also triggered several "integrity" reforms, including the creation of the Independent Parliamentary Standards Authority (IPSA) to regulate MPs' pay, and legal changes to the tax status of the members of the House of Lords (Worthy \& Hazell, 2013). Local authorities saw FOI as one part of a wider set of integrity structures that meant they "would not do anything they wouldn't feel comfortable with in the local newspaper" (Worthy et al., 2011). The evidence so far points to the power of FOIs "unpredictability," as the inability to know when and where requests can come from generates uncertainty, which may in turn affect behavior (Worthy, 2013).

Yet there may be negative effects. Some claim FOI triggers a chilling effect whereby the record is either reduced or exists "off paper," a process labeled the "empty archives" phenomenon in Sweden (Ostberg \& Erikkson, 2009, pp. 118-119). Skeptics argue a balance needs to be struck between access to decision-making information against the need to enable "accurate and sufficiently full" discussion, "full, frank advice" and, if necessary "honest disagreements" when formulating policy (Justice Committee, 2012, p. 54). A former Cabinet Secretary and Justice Minister both argued that a "chilling" took place, though they offered anecdotes rather than firm evidence (Justice Committee, 2012, pp. 74-75). The Justice Committee "was not able to conclude, with any certainty, that a chilling effect has resulted from the FOI Act" (Justice Committee, 2012, p. 75). A study of U.K. central government found "rare" and "isolated" occurrences but concluded that "changes in recording were due to other factors ... Moreover, many officials pointed out that the dangers of not having a decision outweighed the dangers of having one and it being released" (Worthy, 2010, p. 571).

Indeed "resources, fear of leaks and changing decision-making styles" all appeared to have more impact than FOI (Worthy, 2010, p. 571). Similarly, at local level specific incidents were identified, but no conclusive link was found (Worthy et al., 2011). Measuring such an effect is fraught with difficulties and also presupposes that the actual politics of decision making are always written down (Worthy, 2010). However, as with concern over media "abuse," the claim that such an effect may exists may encourage caution in others and may itself prove self-fulfilling.

A further problem is that the arrival of FOI paralleled the rise of "blame avoidance" and "spin," so that the arrival of FOI clashes with a growing pressure to control information (A. S. Roberts, 2005). In the United Kingdom, there was evidence of "game-playing" by some parts of government, with 
attempts to deflect, hide, or delay information release (Hazell et al., 2010). FOI and "spin" highlight a conundrum for public bodies as to how open to be. This was seen in the case of expenses, when both the Scottish and U.K. Parliament received requests for details of Members' expenses claims. The former quickly published all expenses, experiencing little scandal after one Member of the Scottish Parliament resigned (Dunion, 2011). By contrast, the U.K. Parliament's drawn out attempt to withhold expenses undoubtedly worsened the situation. Yet such a "total" openness approach is unlikely to be welcomed and may not always work.

This assessment from the perspective of integrity clearly highlights FOI's contribution to curbing corruption and unwarranted spending of public officials. At the same time, there is debate about the extent to which transparency stifles government. Research of these impacts is difficult and has not resulted in conclusive findings. The important question is whether additional measures need to be taken to ensure that transparency prevents corruption without inflicting upon the space to think and privacy of individual civil servants.

\section{Resilience?}

In so far as it can be measured, the resilience of public bodies has been slightly improved by transparency. The increased professionalization, better internal information flows, and improved records management would all be likely to reduce "risk." Both central government and local government identified a "cleaning up" and professionalizing of records (Worthy et al., 2011, pp. 17-18). A National Health Service representative also identified a "change in culture in decision-making" and greater engagement with the public (Justice Committee, 2012, p. 19). Other bodies identified increased engagement with stakeholders and, in a few cases, better relations with the media (Hazell et al., 2010). Taken together, these improvements may make a public body more resilient, more responsive to external views and mitigate the risks of, for example, embarrassing leaks.

Yet there exists skewed patterns within use that may trigger underperformance and poor perceptions. Certain issues and areas of government attract far more "FOI attention" than elsewhere. Local government attracts somewhere between $70 \%$ and $80 \%$ of all FOI requests and there is evidence that poorly performing local authorities may attract more FOIs in sensitive areas than those better performing ones (Worthy, 2013). At central government level, there is variation between departments. In 2013, the Department of Works and Pensions, engaged in controversial welfare reform, received 5,600 FOI requests, the Home Office 3,500 while the Department of Culture received only 700 (MOJ, 2014). Unsurprisingly, the activities of MPs remain of interest to requesters and the media, with a spillover conflict between the 
new regulator IPSA and groups of MPs and a continued "drip" of minor scandals (Worthy \& Hazell, 2013).

The minority of "political" requests tend to cluster around controversy, and disclosure may further fan controversy and attention, amplifying "problems." The response of public bodies may then further aggravate the situation. FOI use can be met with variable responses, from total openness to a "bunkering down" but those that choose resistance run the danger of further attention (Heald, 2012; Worthy, 2013). The danger is that, while the "best" get better and more open, the "worse" get worse, more secretive and even more of a target, in a self-perpetuating cycle of conflict. Such conflict also feeds the arguments of critics that FOI leads to conflict and is being "abused." The emergence of narrative that transparency is being "abused" and a "resource burden" may well hamper resilience more than the actual effects of the Act.

The assessment from the perspective of resilience highlights that there may be more resilience at an operational level through better information exchanges but, at the same time, resilience at an institutional level may be undermined through the emergence of narrative and perception that transparency is being "abused" and a "resource burden." This may result in an unwillingness to cooperate with citizens or stakeholders. The question here is how and whether increased monitoring of government agencies and officials can strengthen operational resilience without undermining relations of trust or whether "it is a price well worth paying for the benefits greater openness brings" (Justice Committee, 2012, p. 18).

Overall, applying a multiperspectivist lens to the administrative realm has resulted in the identification of a variety of pros and cons and also of three additional questions that are relevant to debates about current and future forms of FOI in the United Kingdom:

- How can the current FOI regime be developed further as to strengthen the overall focus on economy and efficiency through directed and proactive forms of transparency?

- Is there a need for additional measures to ensure that transparency prevents corruption without inflicting upon the space to think and privacy of individual civil servants?

- How can the increased monitoring of government agencies and officials on the basis of FOI strengthen operational resilience without undermining relations of (international) trust in the public sector?

This means we have identified three questions for the administrative realm and previously we had identified three questions in the political realm. These questions have been based on the political and administrative logics but, in 
view of the permeability between politics and administration, the questions may "travel" between the realms. The question about corruption versus privacy, for example, may also be raised in the political realm and the question about citizen empowerment versus inequality between groups may play a role in administrative interactions. In that sense, the analysis of for the two realms helps to identify a rich set of questions and issues.

\section{Conclusion: Toward a "Golden Mean" of Government Transparency?}

We have developed an interpretative assessment framework that can hopefully be helpful to advance debates about the required level of transparency and establish the need for transparency in a specific situation. The argument driving this article has been threefold:

1. Transparency assessment can never be reduced to simple metrics and box-ticking exercises as it requires explicit incorporation and comparison of distinct political and administrative value sets;

2. The complexity argument does not mean that transparency cannot be evaluated. There is a need for an instrument that helps stakeholders to engage in a structured debate about the question to what extent different forms of transparency result in desirable outcomes. That means the different normative claims need to be structured and/or interpreted in terms of underlying value sets pertinent to the assessment of government transparency;

3. Articulating these value sets and inducing stakeholders and evaluators to systematically engage in more structured discursive argumentation offers a conceptually rich yet methodically parsimonious way of identifying areas of consensus and disagreement in the way stakeholders judge the performance of existing and new transparency mechanisms in and around government.

Table 3 synthesizes the core value propositions in the form of a "golden mean" of the criteria sets we have presented in this article. One should note that the precise position of the "golden mean" is by no means universal but contextual and time-bound: The search for the "golden mean" is the key challenge for developing legitimate transparency arrangements. This framework identifies general questions but is not meant for identifying a universal standard for government transparency: The "golden mean" needs to be applied in specific contexts to advance public debate and decision making about specific transparency mechanisms. 
Table 3. Assessing Government Transparency: Synthetic Propositions.

\begin{tabular}{|c|c|c|c|c|}
\hline \multirow{2}{*}{$\frac{\text { Realm }}{\text { Politics }}$} & \multirow{2}{*}{$\begin{array}{l}\text { Perspective } \\
\text { Democracy }\end{array}$} & \multicolumn{3}{|c|}{ Golden mean } \\
\hline & & $\begin{array}{l}\text { Transparency } \\
\text { strengthens civic } \\
\text { competence. }\end{array}$ & $\leftarrow$ & $\begin{array}{l}\text { Transparency creates } \\
\text { inequality between } \\
\text { groups of citizens. }\end{array}$ \\
\hline & $\begin{array}{l}\text { Constitutional } \\
\text { state }\end{array}$ & $\begin{array}{l}\text { Transparency } \\
\text { strengthens checks } \\
\text { and balances. }\end{array}$ & $\leftarrow$ & $\begin{array}{l}\text { Transparency } \\
\text { generates risk } \\
\text { avoidance } \\
\text { and goal } \\
\text { displacement. }\end{array}$ \\
\hline & Learning & $\begin{array}{l}\text { Transparency feeds } \\
\text { public debates } \\
\text { with open } \\
\text { information. }\end{array}$ & $\leftarrow$ & $\begin{array}{l}\text { Transparency } \\
\text { generates public } \\
\text { confusion. }\end{array}$ \\
\hline \multirow[t]{3}{*}{ Administration } & $\begin{array}{l}\text { Economy/ } \\
\text { efficiency }\end{array}$ & $\begin{array}{l}\text { Transparency } \\
\text { produces policy } \\
\text { error reduction. }\end{array}$ & $\leftarrow$ & $\begin{array}{l}\text { Transparency } \\
\text { generates } \\
\text { administrative } \\
\text { burdens. }\end{array}$ \\
\hline & Integrity & $\begin{array}{l}\text { Transparency } \\
\text { prevents } \\
\text { corruption. }\end{array}$ & $\leftarrow$ & $\begin{array}{l}\text { Transparency } \\
\text { inflicts upon the } \\
\text { individual space } \\
\text { to think. }\end{array}$ \\
\hline & Resilience & $\begin{array}{l}\text { Transparency } \\
\text { facilitates risk } \\
\text { management. }\end{array}$ & $\leftarrow$ & $\begin{array}{l}\text { Transparency } \\
\text { amplifies risk } \\
\text { (perceptions). }\end{array}$ \\
\hline
\end{tabular}

To advance our understanding of the different assessments of transparency, the framework needs to be applied differently in different countries. Previous work suggests that transparency has a different impact in different institutional and cultural settings (Grimmelikhuijsen, Porumbescu, Hong, \& Im, 2013; Worthy \& Grimmelikhuijsen, 2012). The framework may also need to be applied differently for different policy realms as undesirable effects such as risk avoidance and goal displacement may emerge more rapidly in controversial than in more technical realms. Our knowledge about the specific relations between the institutional and cultural context and resulting effects is still limited and especially the differences in transparency arrangements and outcomes of democratic and (semi)authoritarian states merit more research (cf. Rodan, 2004). Using the framework in different policy, institutional and cultural settings will help to develop a sophisticated understanding of the relation between context and assessment of various types of transparency arrangements.

A limitation of our framework is that it helps to assess specific questions, but it does not stipulate how these dimensions relate, interact, and/or conflict. 
Transparency in one dimension may yield positive effects in another dimension, but it may also result in an excess of transparency with perverse effects in other dimensions. The positive spillover effects from one transparency dimension to another are certainly no given. Rodan (2004) argues that transparency in one dimension - transparency for (financial) resilience-may falsely generate the impression that transparency is also created for democracy and constitutional checks and balances. The relations between these dimensions need to be investigated in further research.

We would like to stress that the balance that we discuss is specifically relevant for states that already have a reasonably high level of openness. The discussion about a balance should not be abused to curtail transparency and deny citizens, journalists, stakeholders, and NGOs access to a basic access to information. The objectives of democracy, checks and balances, learning, economy/efficiency, integrity, and resilience are served by a certain level of transparency and drawbacks only occur at a high level of it. There can be no doubt that states should enact fundamental rights of access to information to empower citizens. The argument in this article should be understood in relation to those that are arguing for full transparency and highlights that, at a high level of openness, perverse or unintended effects may become dominant.

When it comes to government transparency, we are only starting to understand the variety in potential benefits and drawbacks. Many analyses focus on a limited set of benefits and drawbacks which makes these analyses of only limited usefulness (e.g., O'Neill, 2002; Welch, 2012). The interpretative assessment framework presented in this article provides an effective heuristic tool for progressing our understanding. While the complexity of the values at stake defies straightforward operationalization and measurement of the criteria proposed, this article provides an interpretative assessment framework to bring focus and nuance to the often heated debates. The framework is no calculative measurement tool that will result in a conclusive judgment about the desired level of transparency, but it does provide an interpretative framework for systematically analyzing the (de)merits of transparency in a wide variety of political and administrative contexts.

\section{Declaration of Conflicting Interests}

The author(s) declared no potential conflicts of interest with respect to the research, authorship, and/or publication of this article.

\section{Funding}

The author(s) received no financial support for the research, authorship, and/or publication of this article. 


\section{References}

Bannister, F., \& Connolly, R. (2011). The trouble with transparency: A critical review of openness in e-government. Policy \& Internet, 3(1), Article 8, 1-30.

Barber, B. R. (1984). Strong democracy: Participatory politics for a new age. Berkeley: University of California Press.

BBC. (2012, October 2). Walberswick parish councillors quit over FOI requests. Retrieved from http://www.bbc.co.uk/news/uk-england-suffolk-19804046

Blair, T. (2010, September 1). World exclusive interview with Tony Blair. The Guardian. Retrieved from http://www.guardian.co.uk/politics/2010/sep/01/tonyblair-a-journey-interview

Bovens, M., Schillemans, T., \& 't Hart, P. (2008). Does public accountability work? An assessment tool. Public Administration, 86, 225-242.

Boyne, G. A., James, O., John, P., \& Petrovsky, N. (2009). Democracy and government performance: Holding incumbents accountable in English local governments. The Journal of Politics, 71(4), 1273-1284.

Colquhoun, A. (2010). The cost of freedom of information. London, England: Constitution Unit.

Comfort, L. K., Boin, A., \& Demchak, C. (Eds.). (2010). Designing resilience. Pittsburgh, PA: University of Pittsburgh Press.

Curtin, D., \& Meijers, H. (1995). The principle of open government in Schengen and the European Union: Democratic retrogression? Common Market Law Review, 32, 391-442.

De Fine Licht, J., Naurin, D., Esaiasson, P., \& Gilljam, M. (2013). When does transparency generate legitimacy? Experiment on a context-bound relationship. Governance, an International Journal of Policy, Administration, and Institutions, 27, 111-134. doi:10.1111/gove.12021

Draghi, M., Francesco, G., \& Merton, R. C. (2004). Transparency, risk management and international financial fragility (Geneva Reports on the World Economy, 4). Geneva, Switzerland: International Center for Monetary and Banking Studies and London, Centre for Economic Policy Research.

Drew, C., \& Nyerges, T. (2004). Transparency of environmental decision-making: A case study of soil cleanup inside the Hanford 100 area. Journal of Risk Research, 7, 33-71.

Dror, Y. (1999). Transparency and openness of quality democracy. In M. Kelly (Eds.), Openness and transparency in governance: Challenges and opportunities (pp. 25-43). Maastricht, The Netherlands: NISPAcee Forum.

Dryzek, J., \& Niemeyer, S. (2010). Foundations and frontiers of deliberative governance. Oxford, UK: Oxford University Press.

Dunion, K. (2011). Freedom of information in Scotland in practice. Dundee, Scotland: Dundee University Press.

Erkkilä, T. (2012). Government transparency: Impacts and unintended consequences. New York, NY: Palgrave Macmillan.

Etzioni, A. (2010). Is transparency the best disinfectant. The Journal of Political Philosophy, 18, 389-404. 
Ferreira da Cruz, N., Tavares, A. F., Marques, R. C., Jorge, S., \& De Sousa, L. (2015). Measuring local government transparency. Public Management Review. Advance online publication. doi:10.1080/14719037.2015.1051572

Freund, P. A. (1972). The Supreme Court of the United States: Its business, purposes and performance. Gloucester, MA: Peter Smith.

Fung, A. (2013). Infotopia: Unleashing the democratic power of transparency. Politics \& Society, 41, 183-212.

Fung, A., Graham, M., \& Weil, D. (2007). Full disclosure: The perils and promise of transparency. Cambridge, UK: Cambridge University Press.

Grimmelikhuijsen, S. G. (2012). Transparency and trust: An experimental study of online disclosure and trust in government (Doctoral thesis). Utrecht University, The Netherlands.

Grimmelikhuijsen, S. G., Porumbescu, G., Hong, B., \& Im, T. (2013). The effect of transparency on trust in government: A cross-national comparative experiment. Public Administration Review, 73, 575-586.

Habermas, J. (1981). The theory of communicative action, Vol. 1: Reason and the realization of society. Boston, MA: Beacon Press

Hazell, R., Bourke, G., \& Worthy, B. (2012). Open house? Freedom of information and its impact on the UK parliament. Public Administration, 90, 901-921.

Hazell, R., \& Worthy, B. (2010). Assessing the performance of freedom of information. Government Information Quarterly, 27, 352-359.

Hazell, R., Worthy, B., \& Glover, M. (2010). The impact of freedom of information on British Central Government: Does FOI work? London, England: Palgrave Macmillan.

Heald, D. (2003). Fiscal transparency: Concepts, measurement and UK practice. Public Administration, 81, 723-759.

Heald, D. (2006). Varieties of transparency. In C. Hood \& D. Heald (Eds.), Transparency: The key to better governance? (pp. 25-43). New York, NY: Oxford University Press.

Heald, D. (2012). Why is transparency about public expenditure so elusive? International Review of Administrative Science, 78, 30-49.

Hirschman, A. O. (1991). The rhetoric of reaction: Perversity, futility, jeopardy. Cambridge, MA: The Belknap Press of Harvard University Press.

Hood, C. (1991). A public management for all seasons? Public Administration, 69, 3-19.

Hood, C. (2006). Transparency in historical perspective. In C. Hood \& D. Heald (Eds.), Transparency: The key to better governance? (pp. 4-23). Oxford, UK: Oxford University Press.

Hood, C. (2010). Accountability and transparency: Siamese twins, matching parts, awkward couple. West European Politics, 33, 989-1009.

Hood, C., \& Heald, D. (Eds.). (2006). Transparency: The key to better governance? New York, NY: Oxford University Press.

James, O. (2011). Performance measures and democracy: Information effects on citizens in field and laboratory experiments. Journal of Public Administration Research and Theory, 21, 399-418. 
James, O., \& Moseley, A. (2014). Does performance information about public services affect citizens' perceptions, satisfaction and voice behaviour? Field experiments with absolute and relative performance information. Public Administration, 92, 493-511.

Justice Committee (House of Commons). (2012). Post-legislative Scrutiny of the Freedom of Information Act 2000; Volumes 1 and 2 [HC 96-i]. London, England: The Stationary Office.

Keane, J. (2009). The life and death of democracy. London, England: Simon \& Schuster.

Lagsten, J., \& Goldkuhl, G. (2008). Interpretative IS evaluation: Results and uses. The Electronic Journal Information Systems Evaluation, 11, 97-108.

Lindblom, C. E. (1965). The intelligence of democracy. New York, NY: Free Press.

Margetts, H. (2011). The internet and transparency. The Political Quarterly, 82, 518-521.

Meijer, A. J. (2007). Publishing public performance results on the Internet. Do stakeholders use the Internet to hold Dutch public service organizations to account? Government Information Quarterly, 24, 165-185.

Meijer, A. J. (2013). Understanding the complex dynamics of transparency. Public Administration Review, 73, 429-439.

Meijer, A. J., Curtin, D., \& Hillebrandt, M. (2012). Open government: Connecting vision and voice. International Review of Administrative Sciences, 78, 10-29.

Ministry of Justice. (2012). Government response to the Justice Committee's Report: Post-legislative scrutiny of the Freedom of Information Act 2000 (Cm 8505). Retrieved from http://www.justice.gov.uk/downloads/publications/policy/moj/ gov-resp-justice-comm-foi-act.pdf

Ministry of Justice. (2014). Statistics on implementation in central governmentOctober-December 2013 and Annual. Retrieved from https://www.gov.uk/ government/uploads/system/uploads/attachment_data/file/305525/foi-act2000-statistics-implementation-in-central-government-2013-q4-annual.pdf

Moss, G., \& Coleman, S. (2014). Deliberative manoeuvres in the digital darkness: E-Democracy Policy in the UK. The British Journal of Politics \& International Relations, 16(3), 410-427.

Naurin, D. (2006). Transparency, publicity, accountability - The missing links. Swiss Political Science Review, 12(3), 90-98.

O'Neill, O. (2002). A question of trust. Cambridge, UK: Cambridge University Press.

Ostberg, K., \& Erikkson, F. (2009). The problematic freedom of information principle: The Swedish experience. In A. Flinn \& H. Jones (Eds.), Freedom of information: Open access, empty archives? (pp. 113-125). London, England: Palgrave.

Park, H., \& Blenkinsopp, J. (2011). The roles of transparency and trust in the relationship between corruption and citizen satisfaction. International Review of Administrative Sciences, 77, 254-274.

Pattie, C., \& Johnston, R. (2012). The electoral impact of the UK 2009 MPs' expenses scandal. Political Studies, 60, 730-750.

Piotrowski, S. J., \& Borry, E. (2010). An analytic framework for open meetings and transparency. Public Administration and Management, 15(1), 138-176. 
Prat, A. (2005). The wrong kind of transparency. American Economic Review, 95, 862-877.

Roberts, A. (2006). Blacked out: Government secrecy in the information age. Cambridge, UK: Cambridge University Press.

Roberts, A. S. (2005). Spin control and freedom of information: Lessons for the United Kingdom from Canada. Public Administration, 83, 1-23.

Roberts, A. S. (2012). Wikileaks: The illusion of transparency. International Review of Administrative Sciences, 78, 116-133.

Roberts, J. (2009). No one is perfect: The limits of transparency and ethic for "intelligent" accountability. Accountability, Organization and Society, 34, 957-970.

Rodan, G. (2004). Transparency and authoritarian rule in Southeast Asia, Singapore and Malaysia. New York, NY: Routledge.

Stiglitz, J. E. (1999). On liberty, the right to know, and public discourse: The role of transparency in public life. Oxford, UK: Oxford Amnesty Lecture.

Svara, J. H. (2001). The myth of the dichotomy: Complementarity of politics and administration in the past and future of public administration. Public Administration Review, 61, 176-183.

van Twist, M., van der Steen, M., Kleiboer, M., Scherpenisse, J., \& Theissens, H. (2013). Coping with very weak primary schools: Towards smart interventions in Dutch education policy (OECD Education working Papers No. 98). Retrieved from http://ideas.repec.org/p/oec/eduaab/98-en.html

Vivyan, N., Wagner, M., \& Tarlov, J. (2012). Representative misconduct, voter perceptions and accountability: Evidence from the 2009 House of Commons expenses scandal. Electoral Studies, 31(4), 750-763.

Welch, E. W. (2012). The relationship between transparent and participative government: A study of local governments in the United States. International Review of Administrative Sciences, 78, 93-115.

Werner, W. (1978). Evaluation: Sense-making of school programs. Occasional Paper No.11, Curriculum, Media \& Instruction Dept of Secondary Educaton, University of Alberta, Canada.

White, N. (2007). Free and frank: Making the official information act work better. Wellington, NZ: Institute of Policy Studies.

Worthy, B. (2010). More open but not more trusted? The effect of the Freedom of Information Act 2000 on the United Kingdom central government. Governance, 23, 561-582.

Worthy, B. (2013). "Some are more open than others": Comparing the impact of the Freedom of Information Act 2000 on local and central government in the UK. Journal of Comparative Policy Analysis: Research and Practice, 15, 395-414.

Worthy, B., \& Grimmelikhuijsen, S. (2012, June). How political culture and institutions shape transparency and trust in the $U K$ and the Netherlands. Paper presented at the Transatlantic Conference on Transparency Research, Utrecht, The Netherlands.

Worthy, B., \& Hazell, R. (2013). The impact of the Freedom of Information Act in the UK. In N. Bowles, J. T Hamilton, \& D. Levy (Eds.), Transparency in politics and the media: Accountability and open government (pp. 31-45). London, England: I.B. Tauris. 
Worthy, B., Hazell, R., Amos, J., \& Bourke, G. (2011). Town hall transparency? The impact of FOI on local government in England. London, England: Constitution Unit.

\section{Author Biographies}

Albert Meijer is Professor of Public Innovation at the Utrecht School of Governance of Utrecht University. His research focuses on innovation and technology in the public sector and he has written extensively on governmnet transparency, openness and innovation. Specific themes include transparency, accountability, participation, electronic communication and immigration policies-see http://albert-meijer.nl/

Paul 't Hart is Professor of Public Administration at Utrecht University and Associate Dean of the Netherlands School of Public Administration public leadership (political, bureaucratic, societal); elite behaviour and group dynamics in government; policy evaluation and policy change. His books include Understanding Public Leadership (Palgrave 2014), Oxford Handbook of Political Leadership (co-edited with R.A.W. Rhodes, OUP 2014), and Understanding Prime-Ministerial Performance (co-edited with Paul Strangio and James Walter, OUP 2013). He is co-editor of Political Psychology. [p.thart@uu.nl]

Ben Worthy is lecturer in Politics at Birkbeck College, University of London. Birkbeck College in 2012. His research interests include Government Transparency, Open Data, Political Leadership, British Politics, Digital Democracy. He has written widely on governmnet trasnaprency and Open Data. His blog can be read at https:// opendatastudy.wordpress.com/ 